ment, will be limited to isotopes and labelled compounds not available at Kjeller.

The work of the Physics Department was concentrated on the acquirement of a thorough theoretical understanding of the operation of the reactor and on the establishment of experimental facilities for research utilizing the neutron flux. Equipment available now includes a rotating velocity selector with spiral channels for the investigation of nuclear reaction cross-sections for thermal neutrons, a pile oscillator, a beta-spectrometer of the short-lens type with no iron core, two mass spectrometers and a tenchannel pulse-height analyser with a resolving time of about $20 \mu \mathrm{sec}$. Some preliminary discussions and investigations on new reactor types, with particular reference to ship propulsion reactors, are reported and this work is being continued. A health physicist was appointed to supervise the radiation monitoring programme, and the monitoring instruments which have been in use since the reactor started consist of permanent installations, mainly ionization chambers of the Chalk River type ; semi-permanent monitors and portable monitors of the Harwell type; and personal monitoring equipment, dosimeters and films.

The report concludes with a statement of accounts of the Joint Establishment covering the period July 1, $1951-J u n e ~ 30,1952$; a list of personnel in the various departments ; and details of the information service, together with references to the scientific articles published by members of the staff of the Establishment during the period under review.

\section{CENSUS OF WOODLANDS IN GREAT BRITAIN}

$\mathrm{A}$

MOST interesting report on the census of woodlands in Great Britain has been issued by the Forestry Commission*: The report is based on a comprehensive stocktaking, and this greatly amplifies the information published in 1951 in summary form. The present census was aarried out between January 1947 and June 1949, no fewer than 308,000 tabular reports and maps being submitted by parties of trained surveyors. In the report the methods upon which the material collected was classified are detailed. The woodlands are divided into coniferous high forest, broad-leaved high forest, cuppice and coppice with standards, scrub, devastated woods and felled woodland. The distribution of the woods will probably cause surprise to many. The counties with the largest woodland areas are: Inverness $(212,616$ acres), Yorkshire, Hampshire, Perth, Aberdeen, Sussex, Argyll, Kent and Devonshire; while Montgomery has more than any other county in Wales. All counties have some woodland-London, with 639 acres, or 0.9 per cent of its land area, is actually more densely wooded than Caithness.

The data given are separated for the Forestry Commission and private owner, respectively. The total area of woodland in Britain (excluding woodlands less than 5 acres in extent) at September 30 , 1947, was $3,448,362$ acres, or $6 \cdot 1$ per cent of the land surface of Britain, or only 71 acres of woodland to every 1,000 people. It is stated that Norway has 23.8 per cent of its land surface under trees, Belgium

* Forestry Commission. Census Report No. 1 : Census of Woodlands, 1947-1949; Woodlands of Five Acres and Over. Pp. $264+$ 11 plates. (London: H.M.S.O., 1952.) 12s. $6 d$. net.
$18 \cdot 2$ per cent, and Denmark $9 \cdot 3$ per cent. As is well known, Britain has the lowest percentages of woodland compared with its land area to be found in Western Europe, excepting Ireland and Holland. The comparison is somewhat misleading. Britain is a small island, densely populated and highly industrialized. Timber is essential to these industries; but foresters and agriculturists realize that all land which can produce crops or feed stock must be utilized by the latter. This of necessity sets the limit to the future area of woodlands ; in addition, areas for housebuilding and works have to be eliminated. In each county this matter is now under consideration between those concerned with development and extension of agricultural and forest areas.

The report states that $1,309,569$ acres of the total area of woodland were classified in the census as scrub, devastated or felled areas, largely as the result of overfelling during the two World Wars. This figure, says the report, shows the amount of rehabilitation work necessary to restock these areas. There is some difference of opinion upon one type of woodland classified by the Commission as 'scrub'. There are considerable numbers of poor coppice areas in England so classified, and it is true that the coppice is at present in a poor condition. But this is due to the fact that, when the coppice value decreased, the owners failed to continue to replace the old stools as had been done periodically in the past from the time the area had been treated as coppice.

\section{JOURNAL OF EMBRYOLOGY AND EXPERIMENTAL MORPHOLOGY}

$\mathrm{T}$ HE first part of a new quarterly journal, the Journal of Embryology and Experimental Morphology, devoted to animal morphogenesis has recently appeared*. Its object is to act as a forum for workers mainly interested in developmental processes to be found in animals at any stage of their life-history. Research work to be published in this new journal will include descriptive, experimental, chemical and physiological embryology, regeneration and healing, developmental changes involved in functional adaptation, growth, ageing, and other aspects of late morphogenesis. Studies of gametes and gametogenesis will be considered for publication, provided they are not primarily of a cytological nature; similarly, work on the physiology of reproduction will be accepted provided it does not more appropriately fall within the scope of any other specialized journal. Aspects of protozoology will also be considered which have a bearing on morphogenesis. Papers on developmental processes in plants will receive favourable consideration, too, if they in any way assist in clarifying zoological aspects of morphogenesis.

The new journal will concentrate mainly on finished pieces of research. This means that the papers published will contain sufficient data, tables and illustrations to make clear the authors' results and conclusions. Preliminary reports and theses, therefore, will not be favourably considered for publication; neither will very long papers. It is hoped, nevertheless, when space permits, to publish theoretical and review papers.

* Journal of Embryology and Experimental Morphology. (Oxford University Press, Amen House, London, E.C.4.) $£ 448$. yearly'; $25 s$ separate issue. 